NOAA

National Marine

Fisheries Service
Fishery Bulletin

¿ established 1881 ๙
Spencer F. Baird

First U.S. Commissione of Fisheries and founder of Fishery Bulletin
Abstract-Accurate maturity-at-age data are necessary for estimating spawning stock biomass and setting reference points for fishing. This study is the first on age at maturity of female sablefish (Anoplopoma fimbria) sampled in Alaska during their winter spawning period, when maturity is most easily assessed. Skipped spawning, the situation where fish that have spawned in the past do not spawn during the current season, was documented in female sablefish for the first time. Determination of age at maturity was heavily influenced by whether these fish that would skip spawning were classified as mature or immature; age at $50 \%$ maturity was 6.8 years when fish that would skip spawning were classified as mature, and 9.9 years when classified as immature. Skipped spawning was more common on the continental shelf, and rates of skipped spawning increased with age through age 15 . Estimates of age at maturity were similar for samples collected in winter and summer, when fish that would skip spawning sampled during winter were classified as mature. When fish that would skip spawning were considered immature in the sablefish population model for Alaska, estimates of spawning biomass decreased. Relative fecundity did not change with size and age, verifying the assumption made in the Alaska sablefish stock assessment that relative reproductive output is linearly related to female spawning biomass.

Manuscript submitted 25 November 2014. Manuscript accepted 20 November 2015. Fish. Bull. 114:89-102 (2016).

Online publication date: 8 December 2015 . doi: $10.7755 / F B .114 .1 .8$

The views and opinions expressed or implied in this article are those of the author (or authors) and do not necessarily reflect the position of the National Marine Fisheries Service, NOAA.

\section{Age at maturity, skipped spawning, and fecundity of female sablefish (Anoplopoma fimbria) during the spawning season}

\author{
Cara J. Rodgveller (contact author) \\ James W. Stark \\ Katy B. Echave \\ Peter-John F. Hulson \\ Email address for contact author: cara.rodgveller@noaa.gov \\ Alaska Biological Laboratories \\ Alaska Fisheries Science Center \\ National Marine Fisheries Service, NOAA \\ 17109 Point Lena Loop Road \\ Juneau, Alaska 99801
}

Although it is generally assumed that marine fish in northern latitudes reproduce on an annual cycle, it is not always the case. For example, it has been documented that a portion of mature Atlantic cod (Gadus morhua) skips spawning annually; therefore, the reproductive cycle for some individuals is longer than 1 year (Marshall et al., 2000). In the North Pacific Ocean, the Pacific halibut (Hippoglossus stenolepis) has been thought to also skip spawning on the basis of their movements during the spawning season (Loher and Seitz, 2008). Skipped spawning, which occurs when mature fish that have spawned in prior seasons do not spawn in the current season, is likely to be a more common phenomenon than previously thought (Rideout and Tomkiewicz, 2011), having been documented in at least 30 freshwater and marine fishes (Secor, 2008; Skjæraasen et al., 2012).

Sablefish (Anoplopoma fimbria) are part of a commercially important resource in the North Pacific Ocean; the fishery in Alaska is val- in population models will lead to bias in estimates of productivity. 
ued at more than $\$ 100$ million annually (Fissel et al. ${ }^{1}$ ). In Alaska, the sablefish population is assessed annually with a split-sex, age-structured population model (Hanselman et al. ${ }^{2}$ ). Age at maturity is an integral component for estimating female SSB, which is used to set target biological reference points for this stock. The current female age-at-maturity model is based on data collected during surveys conducted in the summers of 1978-1983 (Sasaki, 1985). Because these data were collected more than 30 years ago, it is important to re-assess the age at maturity of female sablefish. In addition to potentially being outdated, those ageat-maturity data are from summer samples for which maturity was evaluated macroscopically and was not confirmed with histological examination. These maturity data were also categorized by fish length, the values of which were later converted to ages for stock assessments, introducing further error through the use of an age-length key.

The sablefish is a batch spawner with group synchronous oocyte development and determinate fecundity. This species spawns during the winter or early spring in Alaska. Before this period, immature fish can be unambiguously distinguished from fish that will spawn, and total fecundity can be calculated. During the summer, gonads may be resting and may not show obvious signs that sablefish will spawn in the coming winter; therefore, fish that will skip spawning are difficult to distinguish from fish that will spawn if they are sampled during the summer. If maturity is consistently misclassified when summer samples are used, then estimates of maturity at age can be biased. Skipped spawning has not been documented in sablefish, but skipped spawning rates that have been observed in other species have ranged from $9 \%$ to $86 \%$ (Secor, 2008).

Since 1996, maturity classifications and age data have been collected during the annual summer longline surveys conducted by the NOAA Alaska Fisheries Science Center (AFSC) in Alaska to sample the slope of the Gulf of Alaska, the eastern Bering Sea, and the Aleutian Islands from the end of May through the end of August. Approximately 1000 females are assessed for maturity each year, and about 600 of them are aged. These data have not been incorporated into estimates of age at maturity for stock assessment, but they continue to be collected annually. Until our work

\footnotetext{
${ }^{1}$ Fissel, B. M. Dalton, R. Felthoven, B. Garber-Yonts, A. Haynie, A. Himes-Cornell, S. Kasperski, J. Lee, D. Lew, L. Pfeiffer, J. Sepez, and C. Seung. 2012. Stock assessment and fishery evaluation report for the groundfish fisheries of the Gulf of Alaska and Bering Sea/Aleutian Islands area: economic status of the groundfish fisheries off Alaska, 2011, 299. Alaska Fish. Sci. Cent., Natl. Mar. Fish. Serv., NOAA, Seattle, WA. [Available at website, accessed July 2014.]

${ }^{2}$ Hanselman D. H., C. R. Lunsford, and C. J. Rodgveller. 2013. Assessment of the sablefish stock in Alaska. In Stock assessment and fishery evaluation report for the groundfish resources of the Gulf of Alaska, p. 267-376. North Pacific Fishery Management Council, Anchorage, AK. [Available at website, accessed July 2014.]
}

occurred, there had been no studies of sablefish maturity in winter to compare with the estimates of age at maturity in summer, and there are no estimates of fecundity for sablefish in Alaska.

There were multiple objectives for this study. The first objective was to estimate the age at maturity for prespawning female sablefish caught near the epicenter of their distribution in Alaska and to determine whether females reproduce annually. The second objective was to compare estimates of age at maturity based on histological data from samples collected in winter with estimates of age at maturity based on macroscopic examination of samples collected in summer. The third objective was to determine whether SSB is proportional to fecundity, as is assumed in the population models for sablefish.

\section{Materials and methods}

\section{Winter sampling}

The study area was located off Kodiak Island in the Gulf of Alaska between latitudes $59^{\circ} 03^{\prime}$ and $56^{\circ} 30^{\prime} \mathrm{N}$ and longitudes $148^{\circ} 26^{\prime}$ and $154^{\circ} 35^{\prime} \mathrm{E}$. A commercial trawl vessel, the FV Gold Rush, was chartered to conduct 10 days of fishing beginning 12 December 2011, a period that was estimated to be within the prespawning period for sablefish. To locate specimens for the full range of ages and lengths of mature and immature females, trawling operations were planned for sampling over a wide range of depths and topography, including the continental slope (depths of 500-700 m) and the shelf (depths shallower than $300 \mathrm{~m}$ ), which included bays, gullies, and troughs. Locations were chosen on the basis of catches from commercial fisheries and AFSC bottom trawl surveys. Because of inclement weather, only 4 tows were conducted on the slope, whereas 37 tows were completed on the shelf.

Maturity samples were collected on the basis of a length-stratified sampling design in which up to 7 sablefish were sampled for each centimeter of total length. Each specimen was weighed with the stomach evacuated, and the sagittal otoliths were collected for aging. Both ovaries were excised and weighed. Ovaries were preserved in $10 \%$ formalin. Personnel of the AFSC Age and Growth Program aged otoliths by using standard validated methods (Fargo and Chilton, 1987; Kimura and Anderl, 2005; Kimura et al., 2007).

\section{Maturity classification during winter}

We prepared histological samples from the posterior region of the ovaries for all fish sampled. In addition, for a subsample of specimens representing a range of ovary sizes, the consistency of oocyte development within the ovaries was assessed by using sections from the medial and anterior areas of one ovary and from the posterior section of both ovaries. In another subsample of fish, posterior sections were taken from both ovaries. 


\section{Table 1}

Microscopic (histological) and macroscopic (visual) descriptions of oocyte stage and ovarian maturity of female sablefish (Anoplopoma fimbria) sampled before spawning in the central Gulf of Alaska during December 2011. For the histological classification of ovarian maturity, the most advanced stage of oocytes present is described followed by the maturity stage of the ovary. The stages that were observed are marked with an X.

\begin{tabular}{|c|c|c|c|}
\hline Structures defining maturity & Oocyte stage & Maturity & Observed \\
\hline \multicolumn{4}{|l|}{ Microscopic classification of ovarian maturity } \\
\hline $\begin{array}{l}\text { Oocytes with multiple nucleoli or perinucleolar; } \\
\text { thin ovarian wall. }\end{array}$ & Primary growth & Immature & $\mathrm{X}$ \\
\hline $\begin{array}{l}\text { Oocytes with multiple nucleoli or perinucleolar; } \\
\text { thick ovary wall; thick stroma; blood vessels present. }\end{array}$ & Primary growth & $\begin{array}{l}\text { Mature; } \\
\text { skipped spawning }\end{array}$ & $\mathrm{X}$ \\
\hline Yolk accumulated within eosinophylic spheres (vitellogenesis). & Secondary growth & Mature & $\mathrm{X}$ \\
\hline Yolk spheres have coalesced and yolk has fused. & Oocyte maturation & Mature & $\mathrm{X}$ \\
\hline Ovulatory follicles remain in the ovary after ovulation. & Postovulatory follicle & Mature & \\
\hline
\end{tabular}

Macroscopic classification of ovarian maturity

Ovaries thin and tubular; no oocytes visible.

Immature

$\mathrm{X}$

Ovaries tubular in shape, contain transparent oocytes, which appear indistinct through ovary wall.

Immature

Ova opaque, white, and clearly discernible through the distended, transparent ovary wall.

Ovaries engorged with free-flowing, translucent eggs.

Ovaries large, flaccid, and may be bloodshot.

Ovary small, flaccid; oocytes not discernible.

$\begin{array}{ll}\text { Mature } & \text { X } \\ \text { Mature; spawning } & \text { X } \\ \text { Spent } & \\ \begin{array}{l}\text { Mature; } \\ \text { skipped spawning }\end{array} & \text { X }\end{array}$

Ovarian tissues were embedded in paraffin, sectioned at 5-6 $\mu \mathrm{m}$, stained with hematoxylin, and counterstained with eosin.

Histological slides were examined microscopically by 2 readers, and maturity was classified according to the most advanced ooctye stage or structure contained in the ovary, as well as other features (Table 1) (e.g., Hunter et al., 1992; Stark, 2007). Ovaries with primary growth oocytes as the most advanced stage were classified as immature. However, if ovaries had 1) primary growth oocytes accompanied by a thick stroma and structural reorganization (loose structure of oocytes with tissue surrounding oocytes), 2) blood vessels within the lamellae, and 3) a thick tunica (ovarian wall), the ovaries were classified as resting. Because sampling was conducted immediately before spawning, fish with resting ovaries were classified as fish that would skip spawning in the current spawning season. The presence of thick tunica and stroma before the spawning period has been used as criteria for identifying skipped spawning in multiple fish species, including winter flounder (Pseudopleuronectes americanus [Burton and Idler, 1984]) and Atlantic cod (e.g., Burton et al., 1997; Rideout et al., 2000, 2005; Rideout and Tomkiewicz, 2011). Mature females that had vitellogenic oocytes, hydrated oocytes, or postovulatory follicles were characterized as females that were expected to spawn in the current spawning season. Ovarian wall widths were measured on images taken from the slides used for histological examination. Five measurements were taken and averaged for each fish.

\section{Macroscopic determination of maturity during summer}

Macroscopic determination of maturity has been completed and accompanying otoliths have been collected for aging annually since 1996 during AFSC summer longline surveys, which are conducted from the end of May through the end of August. Sampling stations are spaced systematically $35-55 \mathrm{~km}$ apart along the continental slope of the Gulf of Alaska, the eastern Bering Sea, and the Aleutian Islands (Sasaki, 1985). At each station in the Gulf of Alaska, 7200 hooks are set. For this study, we examined only samples collected in the central Gulf of Alaska (17 stations) for comparison with samples collected during the winter survey. The fish were collected by using a random, systematic method so that samples were taken from all depth strata (100200-m intervals from depths of 200-1000 m).

During the summer, fish are classified as immature, or juvenile, if ovaries are string-like or are slightly enlarged and are clear or pink and contain no visible oo- 
cytes. They are considered mature if ovaries are large, are turning white but still may have a pinkish hue, and veins are developing. For ovaries classified as mature, small oocytes are sometimes discernible and are firmly attached to the tissue. Fish are spawning if eggs are loose or extruding, and they are considered to be resting, or spent, if ovaries are flaccid; spent or resting ovaries may also have a dark coloration. Interpretation of these various stages involves some subjectivity, but technicians are trained to standardize their interpretation of juvenile and mature ovaries.

\section{Estimation of age at maturity}

Age at maturity of female sablefish, for both the histologically analyzed winter samples and the visually analyzed summer samples, was modeled with a logistic function. The 2-parameter logistic function is given by the following equation:

$$
\hat{p}_{\mathrm{a}}=1 /\left(1+e^{-\delta\left(a-a_{50 \%}\right)}\right),
$$

where $\hat{p}_{\mathrm{a}}=$ the estimate of the proportion of mature fish at age;

$\delta=$ the parameter that describes the slope (the speed at which maturity approaches $100 \%)$; and

$a_{50 \%}=$ the parameter that describes the age at which $50 \%$ of the fish are mature.

The observed proportion at age was calculated as

$$
p_{\mathrm{a}}=\frac{m_{\mathrm{a}}}{n_{\mathrm{a}}},
$$

where $m_{\mathrm{a}}=$ the number of mature fish observed at age $a$; and

$n_{\mathrm{a}}=$ the total number of fish at age $a$.

We used the binomial likelihood to fit the observed proportion of mature fish at age with the logistic model given in equation 1 in AD Model Builder. ${ }^{3}$ vers. 11.2 (Fournier et al., 2012), with an additional penalty that accounted for maturity at age 0 being $0 \%$.

Age at maturity was estimated for the winter samples in 2 ways: 1 ) fish that would skip spawning were classified as mature, and 2) they were classified as immature. In actuality, fish that would skip spawning are not immature but have spawned in the past. In the determination of maturity during all previous collections of sablefish in Alaska, fish that would skip spawning were either not distinguished from immature fish or could have been considered mature. For comparison with these data sets, we ran maturity-at-age models with the winter data in which sablefish that would skip spawning were classified as either immature or mature.

Age at maturity was analyzed for all samples pooled and stratified by area, shelf (depths less than $300 \mathrm{~m}$ ), and slope (depths of 500-700 m), to identify possible

\footnotetext{
${ }^{3}$ Mention of trade names or commercial companies is for identification purposes only and does not imply endorsement by the National Marine Fisheries Service, NOAA.
}

differences between these habitats. To examine the relationship between age and skipped spawning the proportion of fish that would skip spawning, by age, was examined for the shelf, where fish that would skip spawning were much more common; ages for which there was only one sample were excluded from this analysis.

\section{Biomass and reference points for target fishing}

Several logistic maturity models were used within the age-structured population model currently used for sablefish in Alaska for determining SSB (Hanselman et al. ${ }^{2}$ ): these included the logistic model fit to the age-atmaturity data from the trawl survey conducted in the winter of 2011, the summer longline survey conducted in 2011, the mean fit to all data from annual summer longline surveys, and the maturity curve currently used in stock assessment.

A time series of female SSB was estimated when each maturity curve was input into the sablefish population model. In short, SSB is calculated in the assessment model with the age structure of the population and the age-at-maturity curve (see Hanselman et al. ${ }^{2}$ ). In addition, $F_{40 \%}$, the fishing rate that reduces SSB per recruit (lifetime egg production) to $40 \%$ of the unfished level, was estimated, for the most current year in the time series, when each of the 4 maturity curves was used to determine SSB in the sablefish population model.

\section{Fecundity}

Ovaries were chosen for estimation of fecundity if they had advanced vitellogenic oocytes and if no postovulatory follicles were identified in histological cross sections; postovulatory follicles would indicate that partial spawning had occurred. In ovaries with these features an advanced (mature) cohort of oocytes was clearly separable from the early developing (immature) cohort on the basis of oocyte size and appearance, as described for sablefish by Mason et al. (1983) and Hunter et al. (1989). This clear separation indicates that sablefish have determinate fecundity, in which there is only one cohort of maturing oocytes within a spawning season. Fecundity was measured with the gravimetric method (Murua et al., 2003), whereby a subsample of mature oocytes is weighed and the number of oocytes is counted. The number of eggs per gram in the subsample is multiplied by the ovary weight to obtain a total fecundity. Samples were taken from the anterior, middle, and posterior sections of both ovaries, and the 6 measurements were averaged to estimate overall fecundity.

As ovaries develop, oocytes enlarge and the number of oocytes per gram of sample weight decreases. Such a decrease will not affect estimates of fecundity unless the decrease is caused by a loss of oocytes through batch spawning or atresia. To confirm that spawning had not commenced, a linear regression of oocytes per gram of subsample weight and fecundity was computed 
and histological slides were examined for postovulatory follicles. Determinations of any oocyte loss due to atresia were done by examination of histological slides. The number of oocytes per gram was also compared for 2 categories of mature fish: younger (age $<12$ years) and older (age $\geq 12$ years) fish. Age 12 is approximately the age at which female sablefish were $100 \%$ mature in most maturity curves in our study. Differing values of the number of eggs per gram of sample weight would indicate a larger egg size for one age group. Additionally, the relationship between relative fecundity (the number of mature oocytes per gram of ovary-free fish weight) and age was examined for indications that relative reproductive output changes with increasing age.

Gonad weight in relation to body weight (gonadosomatic index [GSI], gonad weight/body weight $\times 10$ ) of fish that would skip spawning, as well as spawning and immature fish was determined to see if it could be used to predict spawning status during the winter.

\section{Results}

\section{Distribution of fish on shelf and slope}

Because of weather, sampling in the winter of 2011 was restricted primarily to the shelf; there were 37 tows on the shelf and 4 tows on the slope. In total, 393 female sablefish were sampled: 320 on the shelf and 73 on the slope. The majority of fish from the shelf were smaller and younger than those sampled on the slope (Fig. 1). The average total length of fish was $628 \mathrm{~mm}$ on the shelf and $747 \mathrm{~mm}$ on the slope. Of the samples from the shelf, $90 \%$ (290 of 320 ) were age $1-7 ; 15 \%$ (11 of 73) of the samples taken on the slope were age 2-7, and no age-1 fish were collected on the slope.

\section{Maturity classification for fish sampled during the winter}

Ovarian development was uniform throughout both ovaries for individual fish. Oocyte stages were consistent within the 33 specimens that were assessed at 3 regions in both ovaries. Development of both ovaries was the same in the 188 specimens for which samples were taken from the posterior end of both ovaries. Immature gonads contained only primary growth oocytes and macroscopically looked thin and tubular and had a pinkish hue. Gonads were easily determined to be mature on the basis of the presence of mature, advanced vitellogenic oocytes (Table 1). Without the aid of histological examination, it could be seen that these ovaries were engorged with white, opaque oocytes (Table 1). The cortical alveoli stage was absent from all ovaries.

The second category of mature fish was composed of fish that would skip spawning. These fish had a much thicker tunica than immature fish and sometimes contained atretic primary growth oocytes that had mean wall width of $35 \mu \mathrm{m}$ (95\% confidence intervals [CI] 3041) for immature fish and of $318 \mu \mathrm{m}$ (95\% CI 267-370) for fish that would skip spawning (Fig. 2). They also had thick stroma and blood vessels in the lamellae between oocytes, whereas immature ovaries had tightly packed oocytes with little tissue in between. These characteristics indicated that sablefish exhibit the resting type of skipped spawning, in which vitellogenic oocytes are not produced. Macroscopically, fish that would skip spawning had small ovaries, more similar in size to an immature ovary than to an ovary with yolked oocytes, but they were more flaccid than immature ovaries and had a red coloration. Without adequate experience, or the aid of histological examination, fish that would skip spawning could be mistaken easily for immature fish.

Of 110 mature fish, 23 fish $(21 \%)$ were fish that would skip spawning (here, the number of mature fish 


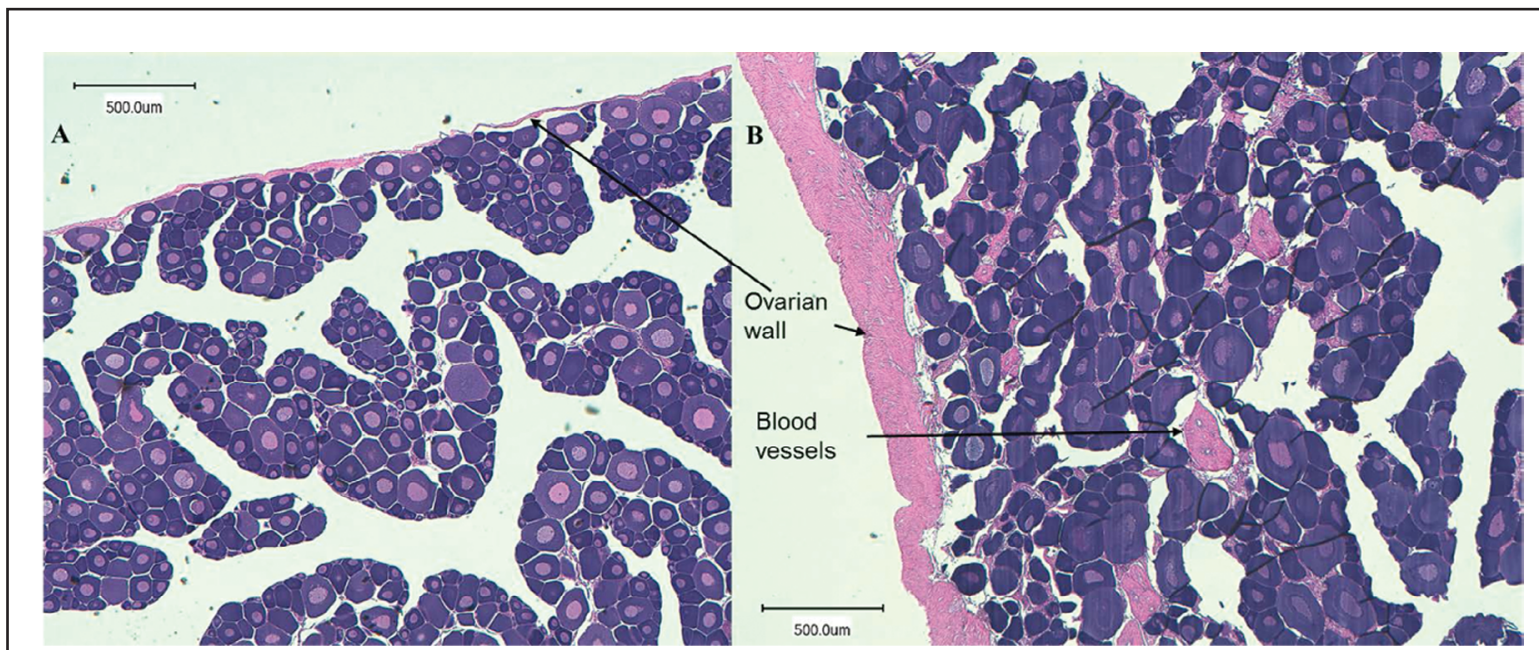

Figure 2

Histological preparations of thin sections of ovaries from sablefish (Anoplopoma fimbria) sampled in the central Gulf of Alaska in December 2011. (A) An ovarian section from an immature fish that has a thin ovarian wall and thin lamellae without blood vessels. (B) An ovarian section from a fish that will skip spawning and has a thicker ovarian wall, thicker lamellae that surround the oocytes, and many blood vessels. In both specimens, there are no maturing, vitellogenic oocytes.

was the sum of the numbers of those that would skip spawning and fish that would spawn in the current season). The great majority of those that would skip spawning (20 out of $23,87 \%$ ) were caught on the shelf, specifically in troughs at stations adjacent to the slope. Most of the fish on the slope were mature (fish that would either spawn or skip spawning, 90\%), but only $4.5 \%$ of mature fish were fish that would skip spawning (3 of 63). Only 14\% of the fish on the shelf were mature and $43 \%$ of these mature fish (19 out of 44) were fish that would skip spawning. Skipped spawning was observed in fish ranging in age from 4 to 17 years, although sample sizes for fish (both mature and immature) $>17$ years of age were often limited to 1 or 2 fish. There was a significant, positive correlation between age and the proportion of mature fish that would skip spawning on the shelf, where the great majority of those that would skip spawning were found (Fig. 3). For that analysis, only fish that were age 4 and older were included, because that age was the first age at which skipped spawning was observed; in addition, only those ages that had a sample size of at least 2 fish were included (ages 4-15) (Fig. 3).

\section{Age at maturity}

The age at maturity of sablefish on the shelf when fish that would skip spawning were classified as mature was dramatically different from the age at maturity when fish that would skip spawning were classified as immature (Fig. 4A). The 95\% CI of each maturity curve did not encompass the other curve. Classifying fish that would skip spawning as mature increased the proportion of fish mature at age. On the slope, age at maturity was also higher when fish that would skip spawning were classified as mature; however, there was not a significant difference (Fig. 4B). The large CIs for slope data can be at least partially attributed to smaller sample sizes.

As with maturity data collected on the shelf, the age at maturity of the pooled samples was significantly different when fish that would skip spawning were classified as mature as opposed to immature (Fig. 4C, solid lines). The $a_{50 \%}$ was 6.8 years when fish that would skip spawning were classified as mature, compared with 9.9 years when they were classified as immature (Fig. 4C, solid lines). When fish that would skip spawning were classified as immature, ages at maturity on the slope and shelf were different. Pooled age at maturity was intermediate between the slope and shelf (Fig. 4C, gray lines). When fish that would skip spawning were classified as mature, age at maturity on the shelf and slope matched closely (Fig. 4C, black lines). The similarity between the 2 age-at-maturity curves indicates that fish in both habitats are mature at the same age but that the majority of fish that would skip spawning reside on the shelf, at least during winter. When fish that would skip spawning were classified as either mature or immature, the pooled data were closer in value to the shelf data because there were more samples on the shelf.

The logistic model fits to the age-at-maturity data from AFSC annual summer longline surveys were variable; $a_{50 \%}$ ranged from 5.5 to 8.6 years and the slope parameters ranged from 0.6 to 1.3 (Fig. 5A). In the winter survey, the proportion of mature fish at age was 


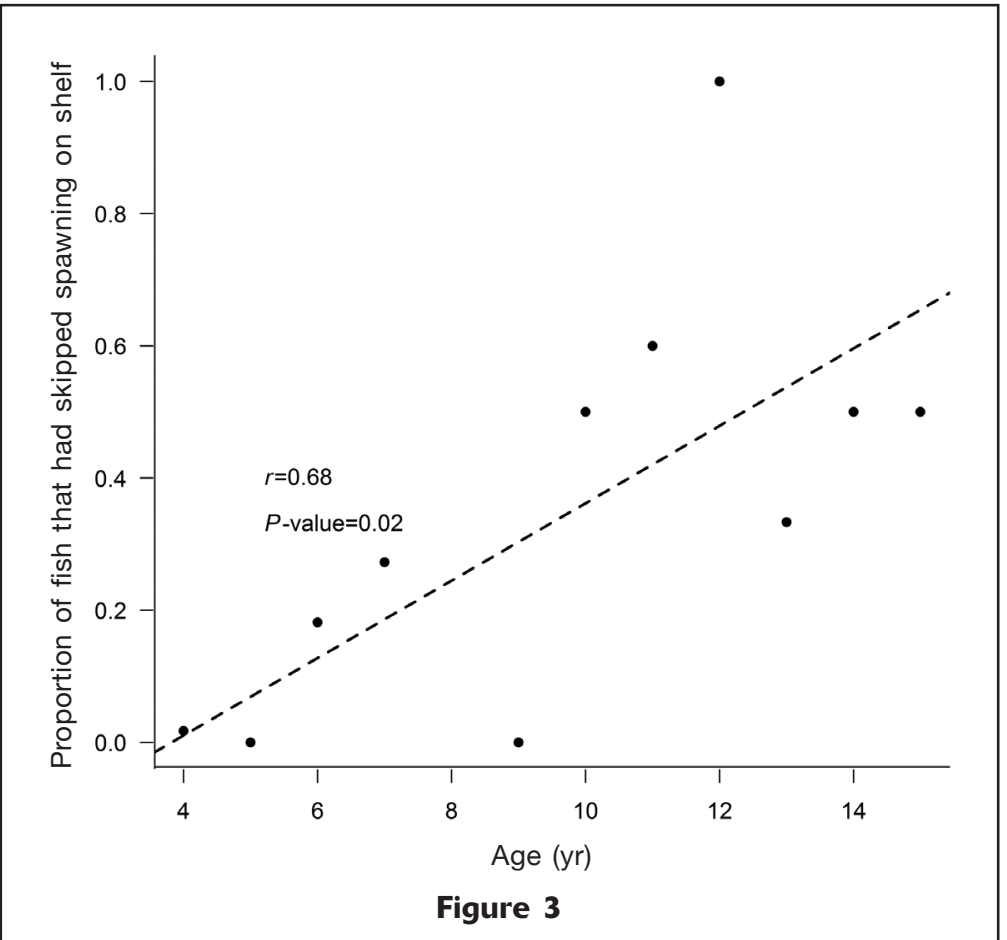

Proportion of mature female sablefish (Anoplopoma fimbria) by age that would skip spawning on the continental shelf in the central Gulf of Alaska in December 2011. Immature fish are not included. The great majority of fish that would skip spawning were found on the shelf. The correlation coefficient $(r)$ with its associated $P$-value is also provided. fied as mature, 8.0 years for samples collected during the summer, and 9.9 years in the winter when fish that would skip spawning were classified as immature. Unlike the majority of curves based on data from the annual summer longline surveys, estimates of the proportion of mature fish in the summer of 2011 were very similar to those from the winter at young ages (Fig. 5B). The difference in the curves based on data from the winter and summer surveys conducted in 2011 can be attributed more to a difference in $a_{50 \%}$ than to a difference in slope.

The estimates of maturity at age currently used in the stock assessment for sablefish in Alaska, determined from samples taken during the summer in the early 1980 s, were higher than the estimates from the winter survey at younger ages (6 years), when fish that would skip spawning were classified as mature (Fig. 5C), but were similar at older ages. The pooled maturity at age for fish captured during the summer longline surveys (from 1996 to 2012) was also higher at younger ages, but it was lower at older ages (Fig. 5C). This pattern can be attributed primarily to differing slopes (Table 2). This trend is the same one that was apparent in the majority of curves fitted to data from the annual summer longline surveys (Fig. 5A). The age-at-maturity values currently used in the stock assessment of sablefish in Alaska and the mean age at maturity from more similar to the proportion in the annual summer longline surveys, when fish that would skip spawning were classified as mature, than when they were classified as immature (Fig. 5A). When fish that would skip spawning were classified as mature (Fig. 5A, black line), the annual estimates of maturity from the summer longline surveys were similar to the estimates from the winter survey at moderate ages (Fig. 5A). At younger ages, the annual estimates of the proportion of mature fish from summer surveys were higher than the estimates from the winter survey; conversely, at older ages, the proportion of mature fish was lower in estimates from the summer survey. When fish that would skip spawning were classified as immature in the winter survey (Fig. 5A, gray line), the estimated proportions of mature fish at each age from the summer surveys were discernibly higher in all years (Fig. $5 \mathrm{~A})$.

The logistic curve fitted to samples taken during the summer of 2011, the year in which the winter survey occurred, was intermediate between the curves from the winter where fish that would skip spawning were classified as mature and the curve where fish that would skip spawning were classified as immature, and the fit was dissimilar to both, especially at moderate ages (Fig. 5B, Table 2). The $a_{50 \%}$ was 6.8 years in the winter when fish that would skip spawning were classi- the annual summer longline surveys were much higher than the values from the winter survey, when fish that would skip spawning were classified as immature (Fig. $5 \mathrm{C})$.

\section{Biomass and target-fishing reference points}

The estimates of SSB were similar when the Alaska sablefish population model was run with the maturity curve fitted to data from the winter survey conducted in 2011 (when fish that would skip spawning were classified as mature), the mean age at maturity across all summer longline surveys, or the maturity curve currently used in stock assessment (base model) (Fig. 5). Estimates of SSB were lower when maturity data were used from the summer longline survey conducted in 2011, and lowest when data were used from the winter survey conducted in 2011 and fish that would skip spawning were classified as immature (Fig. 6). Compared with the base model, the maturity curves based on data from winter and summer 2011 caused larger dips in SSB in years when model projections included large recruitment. The dips in SSB occurred because these maturity curves had lower estimates for the proportion of mature fish at young ages, and such low proportions translate to fewer mature fish when there are more young fish 


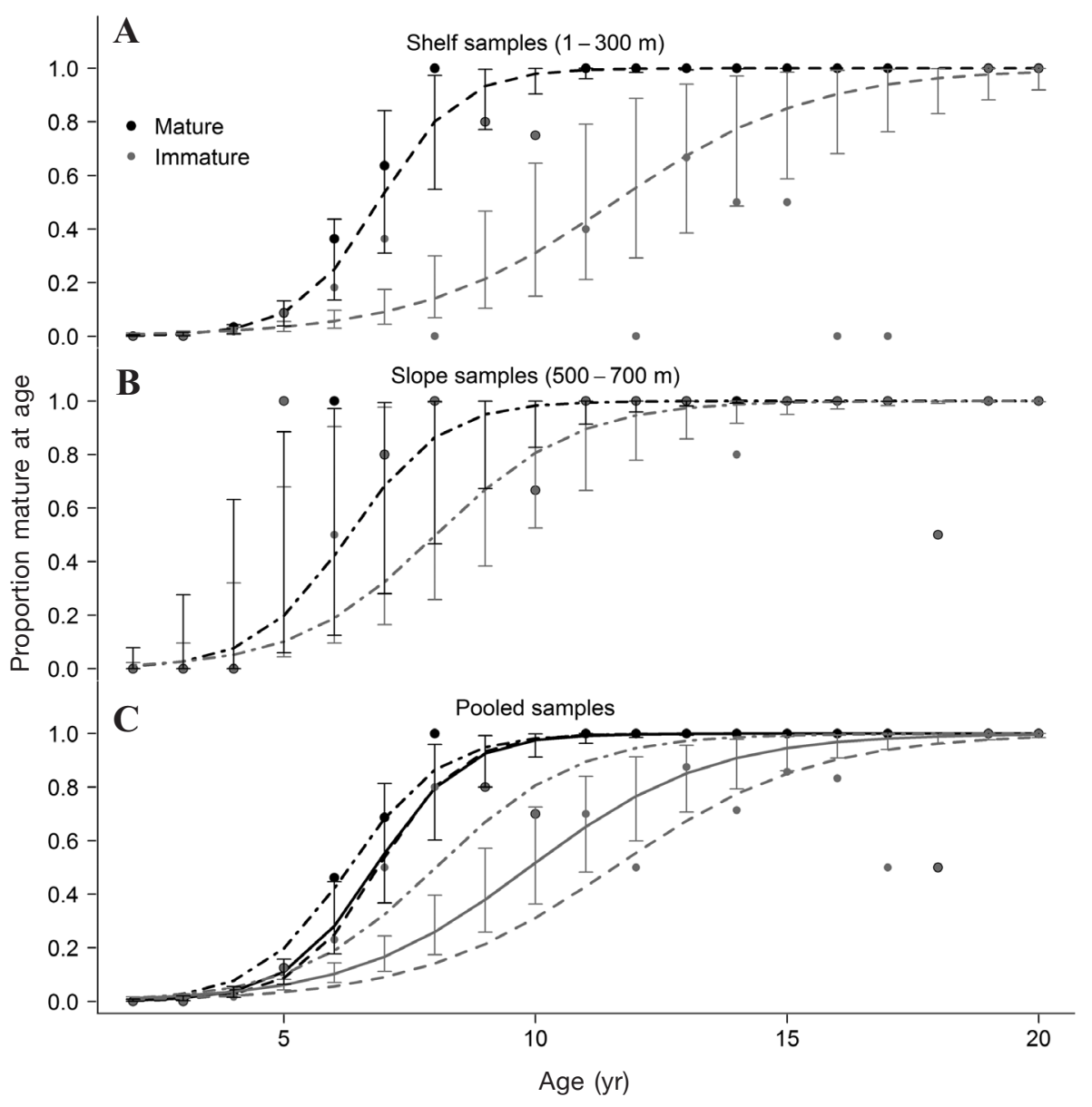

Figure 4

Observed and estimated maturity at age of female sablefish (Anoplopoma fimbria) collected in the winter of December 2011 on the (A) continental shelf, (B) slope, or (C) both shelf and slope (pooled). Fish that would skip spawning were classified as either mature (black points and lines) or immature (gray points and lines). Larger, gray points indicate that data did not differ at that age because there were no fish that were going to skip spawning. Logistic regression models and 95\% confidence intervals at each age are presented. In panel $\mathrm{C}$, solid lines indicate the age at maturity for the pooled samples. The maturity curves (dashed lines) for the shelf and slope, from panels A and B respectively, are also included in panel $\mathrm{C}$ for a comparison with pooled data. The $x$-axis was truncated at age 20 because the proportion mature at ages older than 20 all remained at $100 \%$ and had increasingly small confidence intervals.

in the population. The $F_{40 \%}$ in the most recent year (2013) followed the same pattern: the value from the base model, the mean of summer longline surveys, and value from the winter survey (when SS were classified as mature) were similar: $9.40 \%, 9.45 \%$, and $9.30 \%$, respectively. The data from the summer longline survey conducted in 2011 provided a lower estimate $(8.45 \%)$, and the estimate from the winter survey (when fish that would skip spawning were classified as immature) was the lowest $(7.45 \%)$. A lower $F_{40 \%}$ translates to more conservative management and lower allowable catches.

\section{Fecundity}

Fecundity was calculated for 47 sablefish. Total fecundity, measured as the total number of oocytes per fish that will be spawned in the current season, ranged from 214,577 to 900,700 . There was no evidence of batch spawning (postovulatory follicles) or atresia in any ovaries containing maturing, vitellogenic oocytes. The mean number of oocytes per gram of sample weight was significantly higher for younger fish (ages $<12$ ), with a mean of 10,667 (standard error [SE] 467) than for older fish (ages $\geq 12$ ), with a mean of 8804 (SE 


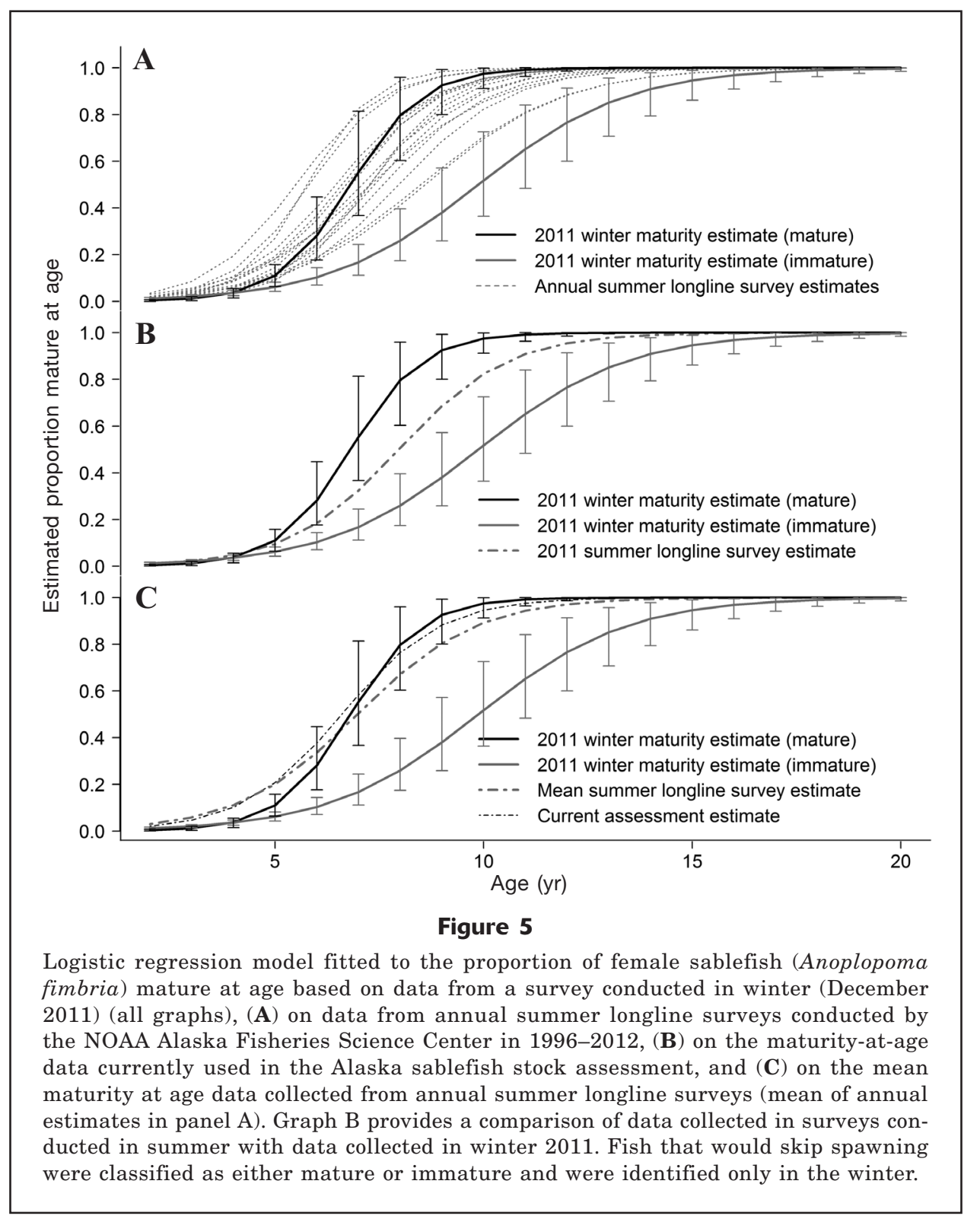

231) ( $t$-test assuming unequal variance: $P=0.001)$, indicating that, on average, younger fish have smaller maturing oocytes. The range in number of eggs per gram of sample weight was greater for younger fish than for older fish.

The relationship between relative fecundity and age was not significant. Very little of the variation in fecundity was explained by age (coefficient of determination $\left.\left[r^{2}\right]=0.02\right)$, and the regression was not significant (slope: $-0.49, P=0.37$; intercept=123). Relative fecundity ranged from 66 to 205 per gram.

The GSI of fish that would spawn (mean $=7.361,95 \%$ lower confidence interval $[\mathrm{LCI}]=6.908,95 \%$ upper confidence interval $[\mathrm{UCI}]=7.814$ ) was much higher than the GSI of fish that would skip spawning (mean=1.064, 95\% $\mathrm{LCI}=0.936,95 \% \mathrm{UCI}=1.191$ ) and of immature fish (mean=0.486, 95\% LCI $=0.471,95 \%$ UCI=0.502). Fish that would skip spawning had a higher GSI than immature fish (there was no overlap of the $95 \% \mathrm{CIs}$ ), although there was some overlap in the raw data (skipped spawning range $=0.486-1.659$; immature range $=0.145-1.110$ )

\section{Discussion}

We found that the logistic models that were fitted to the pooled age-at-maturity data collected during summer longline surveys and to the data currently used in the stock assessment, also collected during the summer, were similar to the maturity curve from the winter data, when fish that would skip spawning were 


\section{Table 2}

Slope and age at 50\% maturity $\left(a_{50 \%}\right)$ determined from logistic models of age at maturity for female sablefish (Anoplopoma fimbria) sampled before spawning during winter (in December 2011) in the central Gulf of Alaska, during summer (May-August), 1996-2012, in the central Gulf of Alaska, and during the summer, 1978-1983, in the Gulf of Alaska. For the winter surveys, fish that would skip spawning were classified as either mature $(\mathrm{m})$ or immature (i). Fish that would skip spawning were not looked for in the summer.

\begin{tabular}{lccc}
\hline Survey & Year & Slope & $a_{50}$ \\
\hline Winter (m) & 2011 & 1.14 & 6.77 \\
Winter (i) & 2011 & 0.56 & 9.88 \\
Summer & 2011 & 0.76 & 7.97 \\
Current assessment & $1978-1983$ & 0.84 & 6.60 \\
Mean (summer longline survey) & $1996-2012$ & 0.70 & 6.98 \\
Range (summer longline survey range) & $1996-2012$ & $0.60-1.30$ & $5.5-8.6$ \\
& & & \\
\hline
\end{tabular}

classified as mature. Additionally, the $a_{50 \%}$ parameters of these logistic models (ranging from 6.60 to 6.98 years) were very similar to recent estimates of age at maturity from the U.S. West Coast that were based on histological findings (6.86 years) (Head et al., 2014). It is unknown if any fish that would skip spawning were sampled in those studies. In our study, the small differences in the maturity curves at young ages caused differences in estimates of female SSB when there were larger than average recruitment classes (see Hanselman et al. ${ }^{2}$ for a time series of recruitment). A lower SSB translated to lower fishing rates $\left(F_{40 \%}\right)$. Compared with data that are currently used in the assessment, the data from the surveys conducted in winter 2011 provided a slightly lower $F_{40 \%}$ when fish that would skip spawning were classified as mature $(0.18 \%)$ and an $F_{40 \%}$ that was $1.95 \%$ lower when these fish were classified as immature. A similar situation has been reported for Atlantic cod, where an overestimation of egg production, by $8-41 \%$, resulted from not accounting for fish that had skipped spawning (Rideout and Rose, 2006). For both species this reduction in SSB should result in a lower allowable biological catch.

For all maturity curves in this study, we used the standard model (i.e., a logistic function with asymptote at $100 \%$ ). The standard model was chosen because it illustrates how differences in age at maturity would impact sablefish management if current methods were used. Although we found that skipped spawning increases with age, our data do not necessarily negate the use of the standard logistic model. The standard model still could be applicable because the increase in skipped spawning occurred at younger ages (4-15), the logistic curves reached $100 \%$ around age 12 (close to age 15), and fish commonly reach ages $>50$. There are many potential methods for incorporating the loss in reproductive output due to skipped spawning depending on how skipped spawning is related to age, the longevity of the species of interest, and the annual or spatial variability in skipped spawning (e.g., Secor, 2008; Brooks, 2013). As more data on the consistency of skipped spawning in the sablefish population in Alaska become available, a complete evaluation of alternative methods for incorporating skipped spawning into the assessment is warranted.

The most direct comparison of estimates of age at maturity for summer and winter was between the samples collected in the winter and summer of 2011. The data from summer 2011 provided estimates of the proportion of mature fish at age that were similar to the values based on data from the winter survey for fish at young ages ( $\leq 5$ years) and that were intermediate between the 2 winter curves for fish at ages 5-13 years. Use of the maturity curve based on data from summer 2011, therefore, produced estimates of SSB, and $F_{40 \%}$ that were also intermediate. It is possible that during the summer some fish that would skip spawning during the upcoming winter were classified as mature and some as immature, and that is why the resulting summer curve was intermediate. It is also possible that fewer fish that would skip spawning were encountered during the summer surveys. The winter survey covered areas on the shelf that were not covered by the summer longline survey in 2011, and the shelf was the area where the majority of these fish were found in the winter. More winter sampling is needed for comparison of winter data with summer data to determine whether the difference we saw in data for 2011 is consistent over time.

It is important to note that we pooled samples from the shelf and slope to produce an overall maturity curve. To test for any bias due to disproportionate sampling in relation to the distribution of the population, we weighted our calculations according to the abundance of fish in each area; abundance values were calculated with data from AFSC bottom trawl surveys conducted in summer. There was little difference between the values from these calculations and the unweighted results, indicating that our results are reflective of the population in Alaska as a whole.

Movement and habitat use during the spawning season have been reported to indicate whether a fish is spawning or has skipped spawning for Pacific halibut (Loher and Seitz, 2008) and Atlantic cod (Hüssy et al., 2009; Jónsdóttir et al., 2014). Sablefish are highly migratory throughout their lives; in Alaska, $11 \%$ of tagged fish have been recovered at locations more than $2000 \mathrm{~km}$ from their release sites (Echave et al., 2013). However, preliminary data from tagging sablefish during the winter survey in 2011 indicate that sablefish do 


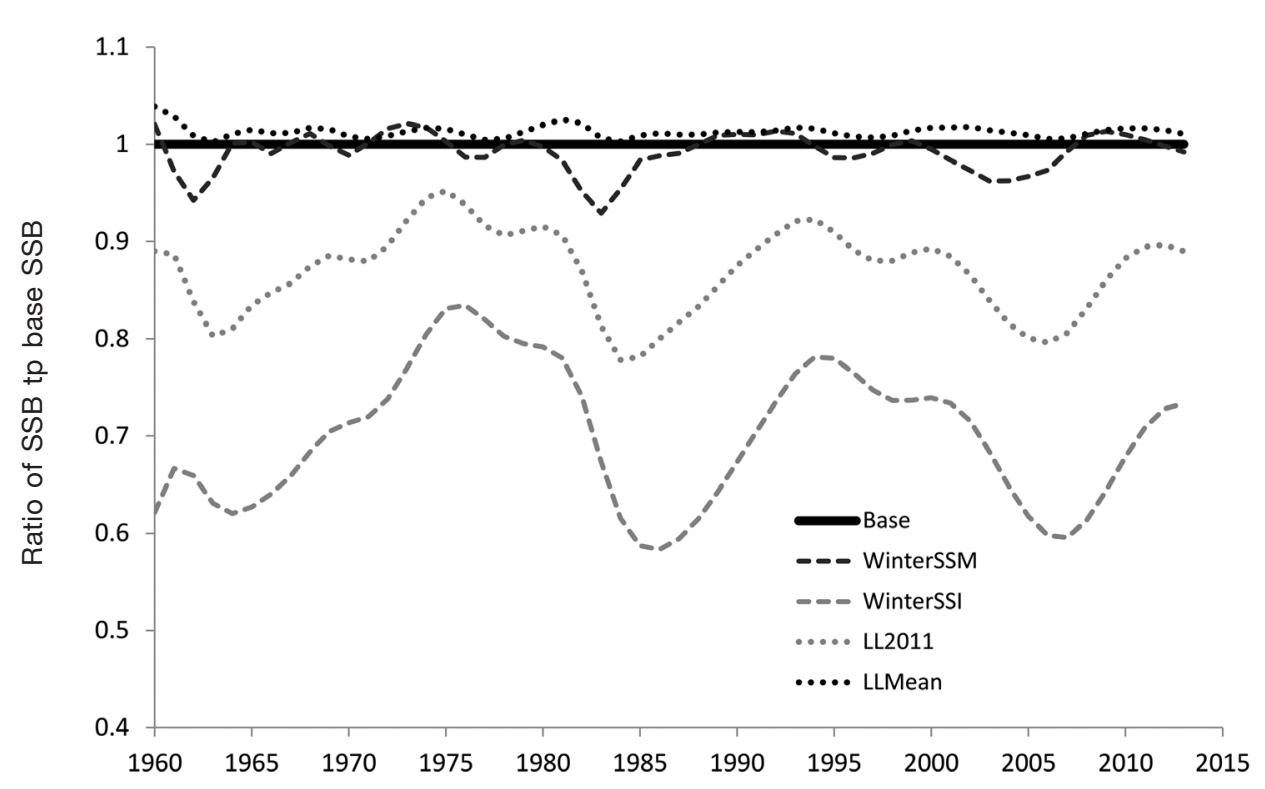

Figure 6

Ratio of the estimates of spawning stock biomass (SSB) when different female maturity curves were incorporated into the population model for sablefish (Anoplopoma fimbria) in Alaska in relation to the SSB when maturity data currently used in the stock assessment of sablefish (base SSB) are used. The maturity curves used in the model included data collected in winter 2011 when fish that would skip spawning were classified as mature (WinterSSM), in winter 2011 when fish that would skip spawning were classified as immature (WinterSSI), in 2011 during the annual summer longline survey conducted by the NOAA Alaska Fisheries Science Center (AFSC) (LL2011), and the mean of data collected during AFSC annual summer longline surveys, 1996-2012.

not move large distances during the spawning season. During the winter survey, we deployed popoff satellite tags on 4 fish $>850 \mathrm{~mm}$ in fork length. We assumed that the tagged fish were female because, in summer longline surveys, only $0.5 \%$ of fish $>850 \mathrm{~mm}$ in fork length have been male. Tags were preprogrammed to pop off fish within the current spawning season (35-52 days after release), and the geolocation of a tag was recorded when it was released from a fish. The 2 fish that were released where they were caught on the shelf remained within $1 \mathrm{~km}$ of their tagging location, and the 2 fish that were captured on the slope but released 75 $\mathrm{km}$ away on the shelf moved to locations in the vicinity of their capture site (within $0.5 \mathrm{~km}$ or $9 \mathrm{~km}$ ).

As with Pacific halibut and Atlantic cod, habitat use by sablefish during the spawning season may be related to spawning. Data on sablefish movement in the winter is greatly lacking because there are no surveys or directed fisheries in the winter. The use of popoff satellite tags enables research on movement to occur during this period. Future research on habitat use and movement related to spawning of sablefish is badly needed both for identifying spawning areas and for tracking the movement of fish that skipped spawning and those that spawned.
Rates of skipped spawning are highly variable among species; a range from $9 \%$ to $86 \%$ has been reported in 21 freshwater and marine species (reviewed in Secor, 2008). Rates are higher for species that have to make large-scale, energetically costly migrations because fish that skip spawning can forgo these migrations. Skipped spawning rates are also hypothesized to be higher for long-lived species because they have the ability to skip spawning to increase their survival and growth and, thereby, to maximize their lifetime reproductive output (Rideout et al., 2005). For example, sturgeons (Acipenseridae), Pacific halibut, and Atlantic cod are long-lived fish that make large-scale spawning migrations and have skipped spawning rates of $10-86 \%$ (Loher and Seitz, 2008; Skjæraasen et al., 2012; Kuhajda, 2014). Sablefish move long distances during their lives, but it is unknown whether their movements are related to spawning. However, they are long-lived and have a maximum age similar to that of other species that skip spawning.

Skipped spawning is related to energy reserves (i.e., relative liver weight) and body condition (the ratio of body weight to length) for Atlantic cod, and rates of skipped spawning can vary by year (Skjæraasen et al., 2009; Skjæraasen et al., 2012). Both of these factors 
indicate that skipped spawning rates may be related to annual environmental conditions and that skipped spawning should be monitored in the future before any conclusions are made on rates in the Alaska population of sablefish. Measurements of relative liver size during the summer may be a good indicator of whether a sablefish will spawn in the coming winter; relative liver size could prove to be a good alternative to histological analysis during the summer. We intend to explore the relationship between energy reserves, spawning, and egg production in the future by sampling both during summer longline surveys and during the winter prespawning period.

Maturity status determined during the summer may be reasonably close to that determined from observations made in the winter, but maturity values based on summer longline surveys are not as accurate. The variability we observed in the estimates from annual summer longline surveys may be attributed to sample size, subjectivity of maturity classification, or fluctuations in the age at maturity or skipped spawning. Inaccuracy in estimates from summer longline surveys could also be the result of survey timing; some fish macroscopically classified as immature during summer surveys may become visibly mature later in the fall and winter, closer to spawning. Another factor that may have caused inaccuracy in estimates is that examination for skipped spawning was not part of the sampling protocol on summer sampling cruises.

It is unknown when fish that would skip spawning stop progressing in development and become distinguishable from spawning fish. For example, in Atlantic cod, fish that would skip spawning could be distinguished histologically at approximately 3 months before spawning but not before (Skjæraasen et al., 2009). If sablefish have a similar development time, this period for distinguishing fish that would skip spawning would fall around October or November, a time that is several months after the end of the annual summer longline surveys. In the future, it will be important to determine the months when immature, skipped spawning, and prespawning sablefish can be differentiated from one another-in order to accurately classify maturity during portions of summer longline surveys, which extend from May through August. Because they exhibited the resting type of skipped spawning and never developed maturing oocytes, fish that will skip spawning can be identified by the absence of vitellogenic oocytes and a thick ovarian wall. Sablefish that will spawn may also have greater energy reserves before spawning; therefore, measurements of body condition and relative liver weight may be useful for predicting spawning (as seen in Atlantic cod, Skjæraasen et al., 2009; Skjæraasen et al., 2012).

The GSI of fish that would skip spawning and immature fish were significantly different for sablefish in this study. The observation of such a difference may not be useful in other species; for example, GSI could not be used to separate skipped spawning and immature Atlantic cod (Skjæraasen et al., 2012). However, this measurement holds great promise for separating immature from skipped spawning sablefish. Although both of these maturity categories showed only early developing, immature oocytes, the additional tissue, such as stroma, blood vessels, and ovarian wall, that we found in the ovaries of fish that would skip spawning, is likely to contribute to the difference observed in GSI values. More data is needed on the GSI of fish that skip spawning to improve our confidence in the use of GSI as a tool for determining maturity.

Comparing the maturity data from the annual summer longline surveys conducted in the Gulf of Alaska, the Aleutian Islands, and the eastern Bering Sea would be beneficial because each fixed station is sampled on the same date each year. Differences in estimates of age at maturity for sablefish from these areas may be a function of the phase of the reproductive cycle when fish were collected. For example, the Bering Sea is sampled in early June, whereas the western Gulf of Alaska is sampled in late August. Ovaries sampled in late August will be more developed and are likely to result in different estimates of age at maturity. Because of the bias that may be introduced as a result of sampling date, winter sampling in multiple areas also is needed to determine whether there is truly geographic variability in maturity at age and skipped spawning. Differences in the age and length at maturity have been documented in sablefish off the coast of the United States, south of Canada (Head et al., 2014); therefore, it will be important to consider geographic differences farther north in Alaska as well.

Our estimates of fecundity were similar to those for sablefish off California (Hunter et al., 1989), but they were higher than estimates from a study off of British Columbia, Canada (Mason et al., 1983). We compared the fecundity of females that were $700 \mathrm{~mm}$ in total length in our study with fecundity determined from other studies because this length is approximately the average female size in the longline fishery for sablefish in Alaska (Hanselman et al. ${ }^{2}$ ). The average fecundity for females $700 \mathrm{~mm}$ in total length was 412,000 eggsa level that was very similar to an estimate from California of 416,000 eggs (Hunter et al., 1989) but more than double the estimate of 182,000 eggs from the British Columbia study (Mason et al., 1983). A microscopic examination of ovarian tissue samples for evidence of postovulatory follicles was not undertaken in the Canadian study; therefore, batch spawning may have occurred but was undetected. If batch spawning occurred, it would decrease the estimated total fecundity and would explain why other studies found higher estimates. Batch spawning was documented for sablefish off central California (Hunter et al., 1989) and likely also occurs in other geographic areas.

We found no significant relationship between relative fecundity and age. This verifies the assumption made in the Alaska sablefish population model that relative reproductive output is linearly related to female spawning biomass and does not change with age. There were few fish older than 25 years ( 3 fish out of 
47) (sablefish maximum age is reported to be 94 years [Kimura et al. 1998]); data from older fish are needed to further test this model assumption.

Although the relative reproductive output did not increase with age, mature oocyte size did. Mature oocyte size could have increased with age because older females have more energy reserves for reproduction than have younger females. These energy reserves could be contributed to development of oocytes, and more energy put to that end would result in larger oocytes. If larger eggs in sablefish increase larval fitness, older females ( $\geq 12$ years, the age at which almost $100 \%$ of fish are mature) may contribute more to the population than do younger females. For example, an increase in energy reserves and survival of larval black rockfish (Sebastes melanops) has been observed for offspring from older, larger females (Berkley et al., 2004). Alternatively, older females may initiate oocyte development earlier than younger sablefish and, therefore, have larger oocytes. Earlier development may also indicate an earlier spawning date for older females, as has been seen in other marine fish species (Stark, 2007; Wright and Trippel, 2009; Rodgveller et al., 2012). Mason's (1984) study of sablefish fecundity indirectly supports the hypothesis that older females spawn earlier than younger females. A decrease in relative fecundity with length could have been caused by an earlier spawning time of larger females. If larger females initiated maturation earlier than smaller females and had spawned at least 1 batch of eggs, the result would be a decrease in relative fecundity with length. Mason may have missed evidence of batch spawning in larger fish because there was no microscopic examination for classification of ovaries in that study.

\section{Acknowledgments}

We thank Captain B. Ashley and the crew of the chartered FV Gold Rush. We also thank our coworkers at NOAA's AFSC: S. Kotwicki; C. Conrath for logistics; D. Anderl for aging otoliths; G. Fleischer and P. Rigby for assistance with the vessel charter; and P. Rigby, J. Heifetz, and D. Hanselman for helpful reviews.

\section{Literature cited}

Berkeley, S. A., C. Chapman, and S. M. Sogard.

2004. Maternal age as a determinant of larval growth and survival in a marine fish, Sebastes melanops. Ecology 85:1258-1264. Article

Brooks, E. N.

2013. Effects of variable reproductive potential on reference points for fisheries management. Fish. Res. 138:152-158. Article

Burton, M. P. and D. R. Idler.

1984. The reproductive cycle in winter flounder, Pseudopleuronectes americanus (Walbaum). Can. J. Zool. 62:2563-2567. Article
Burton, M. P. M., R. M. Penney, and S. Biddiscombe.

1997. Time course of gametogenesis in Northwest Atlantic cod (Gadus morhua). Can. J. Fish. Aquat. Sci. 54(suppl. 1):122-131. Article

Echave, K., D. H. Hanselman, and N. E. Maloney.

2013. Report to industry on the Alaska sablefish tag program, 1972-2012. NOAA Tech. Memo. NMFS F/NWC$254,47 \mathrm{p}$.

Fargo, J., and D. E. Chilton.

1987. Age validation for rock sole in Hecate Strait, British Columbia. Trans. Am. Fish. Soc. 116:776-778. Article

Fournier, D. A., H. J. Skaug, J. Ancheta, J. Ianelli, A. Magnusson, M. N. Maunder, A. Nielsen, and J. Sibert.

2012. AD Model Builder: using automatic differentiation for statistical inference of highly parameterized complex nonlinear models. bOptimiz. Methods Softw. 27:233-249. Article

Head, M. A., A. A. Keller, and M. Bradburn.

2014. Maturity and growth of sablefish, Anoplopoma fimbria, along the U.S. West Coast. Fish.Res. 159:56-67. Article

Hislop, J. R. G.

1988. The influence of maternal length and age on the size and weight of the eggs and the relative frequency of the haddock, Melanogrammus aeglefinus, in British waters. J. Fish Biol. 32:923-930. Article

Hunter, J. R., B. J. Macewicz, and C. A. Kimbrell.

1989. Fecundity and other aspects of the reproduction of sablefish, Anoplopoma fimbria, in central California waters. CalCOFI Rep. 30:61-72. [Available at website, accessed July 2014.]

Hunter, J. R., B. J. Macewicz, N. C.-H. Lo, and C. A. Kimbrell. 1992. Fecundity, spawning, and maturity of female Dover sole Microstomus pacificus, with an evaluation of assumptions and precision. Fish. Bull. 90:101-128.

Hüssy, K., B. Nielsen, H. Mosegaard, and L. W. Clausen.

2009. Using data storage tags to link otolith macro-structure in Baltic cod Gadus morhua with environmental conditions. Mar. Ecol. Prog. Ser. 378:161-170. Article

Jónsdóttir, I. G., V. Thorsteinsson, Ó. K. Pálsson, G. G. Tómasson, and C. Pampoulie.

2014. Evidence of spawning skippers in Atlantic cod from data storage tags. Fish. Res. 156:23-25. Article

Kimura, D. K., and D. M. Anderl.

2005. Quality control of age data at the Alaska Fisheries Science Center. Mar. Freshw. Res. 56:783-789. Article

Kimura, D. K., D. M. Anderi, and B. J. Goetz.

2007. Seasonal marginal growth on otoliths of seven Alaska groundfish species support the existence of annual patterns. Alaska Fish. Res. Bull. 12:243-251. [Available at website, accessed April 2015.]

Kimura, D. K., A. M. Shimada, and F. R. Shaw.

1998. Stock structure and movement of tagged sablefish, Anoplopoma fimbria, in offshore northeast Pacific waters and the effects of El Niño-Southern Oscillation on migration and growth. Fish. Bull. 96:462-481.

Kuhajda, B. R.

2014. Acipenseridae: Sturgeons. In Freshwater fishes of North America. Vol. 1: Petromyzontidae to Catastomidea (M. L. Warren Jr., and B. M. Burr, eds.), p 160-206. John Hopkins Univ. Press, Baltimore, MD.

Loher, T., and A. C. Seitz.

2008. Characterization of active spawning season and depth for eastern Pacific halibut (Hippoglossus steno- 
lepis) and evidence of probable skipped spawning. J. Northwest Atl. Fish. Sci. 41:23-36.

Marshall, C. T., N. A. Yaragina, B. Ådlandsvik, and A. V. Dolgov. 2000. Reconstructing the stock-recruitment relationship for Northeast Arctic cod using bioenrgetic index of reproductive potential. Can. J. Fish. Aquat. Sci. 57:2433-2442. Article

Mason, J. C.

1984. On the fecundity of the sablefish (Anoplopoma fimbria) in Canadian waters. Can. Tech. Rep. Fish. Aquat. Sci. 1290, 17 p. [Available at website.]

Mason, J. C., R. J. Beamish, and G. A. McFarlane.

1983. Sexual maturity, fecundity, spawning, and early life history of sablefish (Anoplopoma fimbria) off the Pacific Coast of Canada. Can. J. Fish. Aquat. Sci. 40:2126-2134. Article

Murua, H., G. Kraus, F. Saborido-Rey, P. R. Witthames, A. Thorsen, and S. Junquera.

2003. Procedures to estimate fecundity of marine fish species in relation to their reproductive strategy. J. Northwest Atl. Fish. Sci. 33:33-54.

Rideout, R. M., M. P. M. Burton, and G. A. Rose.

2000. Observations on mass atresia and skipped spawning in northern Atlantic cod, from Smith Sound, Newfoundland. J. Fish Biol. 57:1429-1440. Article

Rideout, R. M., and G. A. Rose.

2006. Suppression of reproduction in Atlantic cod Gadus morhua. Mar. Ecol. Prog. Ser. 320:267-277. Article

Rideout, R. M., G. A. Rose, and M. P. M. Burton.

2005. Skipped spawning in female iteroparous fishes. Fish Fish. 6:50-72. Article

Rideout, R. M., and J. Tomkiewicz.

2011. Skipped spawning in fishes: More common than you think. Mar. Coast. Fish. 3:176-189. Article
Rodgveller, C. J., C. R. Lunsford, and J. T. Fujioka.

2012. Effects of maternal age and size on embryonic energy reserves, developmental timing, and fecundity in quillback rockfish (Sebastes maliger). Fish. Bull. 110:36-45.

Sasaki, T.

1985. Studies on the sablefish resources in the North Pacific Ocean. Bull. Far Seas Fish. Res. Lab. 22, 108 p.

Secor, D. H.

2008. Influence of skipped spawning and misspecified reproductive schedules of biological reference points in sustainable fisheries. Trans. Am. Fish. Soc. 137:782-789. Article

Skjæraasen, J. E., J. Kennedy, A. Thorsen, M. Fonn, B. N. Strand, I. Mayer, and O. S. Kjesbu.

2009. Mechanisms regulating oocyte recruitment and skipped spawning in Northeast Arctic cod (Gadus morhua). Can. J. Fish. Aquat. Sci. 66:1582-1596. Article

Skjæraasen, J. E., R. D. M., Nash, K. Korsbrekke, M. Fonn, T. Nilsen, J. Kennedy, K. H. Nedreaas, A. Thorson, P. R. Witthames, A. J. Geffen, H. Høie, and O. S. Kjesbu.

2012. Frequent skipped spawning in the world's largest cod population. Proc. Natl. Acad. Sci. 109:8995-8999. Article

Stark, J. W.

2007. Geographic and seasonal variations in maturation and growth of female Pacific cod (Gadus macrocephalus) in the Gulf of Alaska and Bering Sea. Fish. Bull. 105:396-407.

Wright, P. J, and E. A. Trippel.

2009. Fishery-induced demographic changes in the timing of spawning: consequences for the reproductive success. Fish Fish. 10:283-304. Article 